Palupi, G.R.P., Rahmanto, S.W., dan Lestari, S. (2020). Art as a catharsis medium for people with bipolar disorder and synesthesia. Indigenous: Jurnal Ilmiah Psikologi, 5(2). 175-194. doi: https:// doi.org/10.23917/indigenous.v5i2.11229

\title{
Art as A Catharsis Medium for People with Bipolar Disorder and Synesthesia
}

\author{
Galih Ratna Puri Palupi ${ }^{1}$, Septian Wahyu Rahmanto ${ }^{2}$, Sri Lestari ${ }^{3}$ \\ Magister Psikologi Profesi, Universitas Muhammadiyah Surakarta ${ }^{1,2,3}$ \\ galihratnapuripalupi@gmail.com ${ }^{1}$, septianwahyu.ind@gmail.com ${ }^{2}$, sri.lestari@ums.ac.id ${ }^{3}$
}

\begin{tabular}{|l|l|l}
\hline Submitted: 6 June 2020 & Accepted: 8 October 2020 & Published: 30 November 2020 \\
\hline
\end{tabular}

\begin{abstract}
Bipolar disorder is a mood change with manic and depressive phases that disrupt individual activities. People with bipolar disorder $(O D B)$ have both external and internal challenges in life. Bipolar disorder contributes to suicide, so it is important to get attention. ODB can experience altered sensory phenomena that indicate experiences of synesthesia. To maintain the psychological condition of ODB, various therapies can be used, including art therapy. The purpose of this study is to understand the experiences of people with bipolar and synesthesia who use art therapy as a catharsis media to deal with bipolar conditions. This research is a qualitative study using an interpretative phenomenological analysis (IPA) approach. The informants of this study were person with bipolar disorder and synesthesia who maintained his condition using art therapy. From this research, it was obtained a description of the conditions in the depression and synesthesia phases, and three main themes emerged, namely: the way of catharsis during depression, art as a medium for catharsis, and the impact of catharsis through art. Catharsis through art therapy, that is drawing, can help informant deal with bipolar conditions when experiencing manic or depressive episodes. The implication of this research is that art activities that are of interest to clients can be used as a means of performing art therapy. The client's understanding of his condition has an important role in knowing when to start drawing therapy activities.
\end{abstract}

Keywords: bipolar; synesthesia; art therapy; phenomenological research.

\section{INTRODUCTION}

Bipolar is a psychological disorder that its sufferers exist around the world. According to WHO data in 2016, there were 60 million people with bipolar disorder (Kemkes.go.id, 2016). In the United States, 5.7 million adults per year suffer from bipolar disorder (Greenwood, 2020). Head of Bipolar Care Indonesia (BCI), Bandung chapter, Andri Suratman, states that as many as $2 \%$ of Indonesians or 72,860 people suffer from mood disorders or bipolar disorder (Agustina, 2018). One of the contributors to the decrease in the life expectancy of people with bipolar disorder is suicide (Dome, Rihmer, \& Gonda, 2019). Research conducted by Pardede (2012) shows that $62.9 \%$ of suicide attempts were from those with mental health disorders and the majority was bipolar disorder. In the Guidelines for Classification of Mental and Behavioural Disorders (Buku Saku Pedoman Penggolongan Diagnosis Gangguan Jiwa/PPDGJ-III), bipolar disorder is defined as a repetitive mood change (at a minimum of 2 episodes), which disturbs feelings and activities. These changes consist of mania or hypomania - increased affection accompanied by boosted energy and 
activity, and, at other times, depression occurs with decreased affection accompanied by reduced energy and activity (Maslim, 2019).

Research conducted by Herdiyanto, Tobing, and Vembriat (2017) illustrates that the stigma received by People with Mental Disorders (Orang Dengan Gangguan Jiwa/ODGJ) and their family members affected the medical treatment carried out to recover ODGJ conditions. Another effect of this stigma, ODGJ should face health and socio-cultural consequences, such as inadequate treatment, drop-out from medication, shackling, and a contrasting understanding of mental disorders (Lestari \& Wardhani, 2014).

Besides external challenges, people with bipolar disorder also face challenges from themselves. Feelings of people with bipolar disorder change easily from depression to manic and the recurrence is erratic (Santoso, Wubhawa, Ishartono, \& Venty, 2018). Mood changes experienced by people with bipolar disorder cause suffering (Purba \& Kahija, 2018). Bipolar sufferers also tend to experience confusion to solve their mood swings yet they have no idea why it must happen to them. Dean, Gerner, and Gerner (2004) also explain that people with bipolar disorder experience a decrease in quality of life during relapse shown by disturbances in life functions, difficulty in finding a job or struggling in the current job, and difficulties in social interactions. Bipolar disorder is also associated with various clinical comorbidities that affect work, family life, and interpersonal functions (Tinambunan, Amir, Budiman, \& Kusumaningrum, 2018).

Research by Parker, Paterson, Romano, and Graham (2017) regarding the altered sensory phenomena experienced by people with bipolar disorder shows that sufferers experienced synesthesia. Subjects studied by Parker, Paterson, Romano, and Graham (2017) showed synesthesia conditions such as perceiving music in colors or shapes, tasting words, and finding everyday objects that have personality. Synesthesia is a condition in which one characteristic of the stimulus evokes a second experience that is not related to the previous one, for example, in lexical synesthesia, the experience of spoken words can evoke the taste experience (Banissy, Jonas, \& Kadosh, 2014). People with mirror-touch synesthesia report the sensation of touch on their own body when they see another person being touched, it indicates an increase in tactile acuity (Banissy, Jonas, \& Kadosh, 2014; Brang \& Ramachandran, 2011)

Recovery efforts for people with bipolar disorder (ODB) diagnosed with synesthesia are an easy path. Therefore, it requires the ability to face various challenges to survive which is often called resilience. Resilience will appear when someone faces a difficult experience and realizes how to deal with or adapt to it (Florez, 2015). Resilience is referred to as the ability to maintain psychological stability in encountering stress (Keye \& Pidgeon, 2013). One of the efforts to develop resilience is carried out by the " $\mathrm{K}$ " Community, which is a community support group in mental health. This community is a non-profit organization that aims to share knowledge and experiences about the treatment and recovery of schizophrenia and related mental disorders in Solo. "K" Community consists of members with different types of people with mental disorders (ODGJ), such as schizophrenia and bipolar. Recovery efforts for people with bipolar disorder (ODB) usually administer pharmacotherapy and psychosocial interventions which include psychoeducation, cognitive behavioral therapy (CBT), family-focused therapy (FFT), social and interpersonal and social rhythm therapy (Santoso, Wubhawa, Ishartono, \& Venty, 2018). One of the recovery efforts in the " $\mathrm{K}$ " community is carried out with art therapy. Also, it is recommended that people with mental disorders should regularly take medication based on a doctor's prescription.

Art therapy is an intervention technique that combines art and psychology (Sholihah, 2017). Art therapy is based on the idea that the creative process of making art facilitates recovery and is a form of nonverbal communication of thoughts and feelings. This therapy applies art media 
in therapy sessions. The focus of this therapy is to encourage individuals to express themselves visually through activities; building, arranging, mixing, touching, printing, pasting, drawing, photographing, documenting, making films, and so on (Malchiodi, 2011).

Based on the research results, art therapy is useful for improving children's self-concept (Hidayah, 2014), reducing anxiety in women victims of domestic violence (Joseph, Satiadarma, \& Koesma, 2018), accelerating the healing process of psychotic patients (Maftukha, 2017), reducing depression in older adults (Permatasari, Marat, \& Suparman, 2017), and reducing depression symptoms in prisoners (Saputra, Kartasasmita, \& Subroto, 2018).

Several recent studies on bipolar disorder have revealed both life experiences and therapy for people with bipolar disorder. Purba and Kahija (2018) examined three people with bipolar disorder in their 20 s and diagnosed with bipolar disorder for 3 years. This study aims to understand the life experiences of participants as bipolar sufferers using the qualitative method, which is the interpretative phenomenological analysis (IPA) approach. The results of the study found three main themes, namely pre-diagnosis psychological conditions, experiences as bipolar sufferers, and selfacceptance as bipolar sufferers. These results are useful for understanding bipolar sufferers in dealing with mood changes and in accepting their bipolar disorders. Furthermore, research by Yosianto (2013) on people with bipolar disorder inpatient in the hospital found a medium that could be used to monitor and prevent the relapse using a mood chart.

Triswidiastuty, Rusdi, and Rumiani (2019) also conducted a study on five patients with bipolar disorder who are members of the Bipolar Care Indonesia community Yogyakarta chapter. This experimental study with pre-test, post-test, and follow-up in one group was carried out to reduce depression symptoms in bipolar patients by providing interventions in the form of $d h i k r$ (remembrance) therapy. The results showed that dhikr therapy significantly reduced bipolar symptoms. Pardian (2019) also probed 33 years old people with bipolar disorder with a single case design "A-B-A". The results of this study indicate that the application of supportive therapy with guidance techniques improved the meaning of life in people with bipolar disorder.

Previous studies have focused on the experience of people with bipolar disorder without using catharsis media, a media for monitoring people with bipolar disorder, and efforts to reduce symptoms with therapy using experimental methods. This study focuses on understanding the experiences of people with bipolar disorder and synesthesia who apply art therapy as a catharsis medium to deal with bipolar conditions. The research question posed is 'how is the informant's experience in using art therapy as a catharsis medium to deal with bipolar conditions?'

This research is expected to provide a scientific contribution in assisting people with bipolar disorder by psychologists, psychiatrists, and caregivers. For clinical psychology, this research contributes to enriching information about the experiences of people with bipolar disorder in struggling to manage their disorders using art therapy as a catharsis medium.

\section{METHOD}

This qualitative research used the interpretative phenomenological analysis (IPA) approach. According to Smith, Flower and Larkin in Purba and Kahija (2018), the IPA approach aims to explore the subjects' understanding of major experiences in their personal life. The focus of this research is the experiences of bipolar sufferers who manage their condition through art therapy. The informant has used other catharsis media, such as grounding, yoga, and mirroring. However, the catharsis media most frequently used by the informant was drawing. The informant drew realist paintings and doodles. Doodles are simple scribbles or abstracts that are then combined with the 
creativity and imagination of each creator to form a work of art (Anggitasari \& Zaini, 2020). Researchers desire to interpret how informants diagnosed as people with bipolar disorder (ODB) and synesthesia understand their experiences with art therapy.

Table 1.

Demographic data of informant

\begin{tabular}{ll}
\hline \multicolumn{1}{c}{ Characteristics } & \multicolumn{1}{c}{ Informant } \\
\hline Name (initial) & $\mathrm{M}$ \\
\hline Status & ODB \\
\hline Age & 24 y.o \\
\hline Sex & $\mathrm{M}$ \\
\hline Education & Junior High School \\
\hline Diagnose & Bipolar and Synesthesia \\
\hline
\end{tabular}

Researchers recruited informant through the "K" community. This study involved informant of people with bipolar disorder (ODB) and synesthesia who use art therapy as a catharsis medium. The demographic data of informant in this study are shown in Table 1.

Data collection was carried out through semi-structured interviews recorded with a voice recorder with informant consent. The verbatim transcription of the interview was compiled to find the data that revealed the informant's struggle experience using art therapy. The interview was carried out three times at an agreed time and place. The data analysis process was conducted by following the data analysis stage stated by Mahpur (2017), namely: 1) preparing raw data into verbatim; 2) compressing facts; 3) preparing probing for data enrichment; 4) collecting similar facts; 5) determining category; and 6) constructing concepts and narrating. The data validity was achieved using a member check. Sugiyono (2011) states that a member check is used to determine the suitability of the data obtained with that data provided by the informant. A member check was performed so that the information obtained and used in this research is in accordance with the intent of the data source or informant.

\section{RESULTS AND DISCUSSION}

Based on the interviews conducted, there were 3 main themes in the data, namely: 1) The way of catharsis during the depression, 2) Art as a catharsis medium, 3) The impact of catharsis through art. Besides these three main themes, it also obtained depressive phases and synesthesia experiences. Before explaining the main themes, below is a description of depression and synesthesia experienced by the informant.

\section{Description of Depression Phase}

Becoming an individual who is diagnosed with bipolar and synesthesia is a difficult phase of life. In this study, informant $\mathrm{M}$ is 24 years old person who is in the early adulthood phase. Informant $\mathrm{M}$ not only experienced manic and depressive phases in bipolar disorder and synesthesia but also experienced problems with the external environment that affected the mental formation process.

According to Lapsley and Woodbury in Walker, Elison, and Nelson (2017), the early 
adulthood phase is an important period of individual development in the process of developing interpersonal understanding, self-understanding, and self-identity. In this phase, an individual is required to have good adaptability to be able to face life's challenges and be in the period of the personality trait of moratorium, which is the process of self-directing to the exploration of self-identity commitments as well as self-quality to become a prosperous individual. Individual motivation in this phase is very significant in achieving goals supported by excellent physical strength.

Aktu and İlhan (2017) quote Levinson's opinion that early adulthood is also the period when individuals learn how to organize life in a good structure. The life structure referred to by Levinson consists of two components, self-representation, and social relationships. Self-representation is an individual's process of providing expectations, hopes, skills, life goals, values, interpretations of situations, and a picture of oneself. In the life structure, self-representation consists of future projections, life goals, the meaning of life, and perspective on age. Meanwhile, the social relationship is a process of individuals involving themselves with their surroundings, such as family and close friends. The social relationship consists of recreational activities, life decisions, energy focus, and meaningful activities in life.

Depression has major symptoms and other symptoms. According to Maslim (2019), the main symptoms of depression are the effects of depression, loss of interest and excitement, and reduced energy leading to increased fatigue and decreased activities. Other symptoms are decreased concentration and attention, thoughts of guilt and worthlessness, pessimistic future, attempts to harm or suicidal thoughts, disturbed sleep, and loss of appetite.

Informant $\mathrm{M}$ expressed that he is still experiencing a depression phase. The informant experienced a lack of energy, weak physical, cold sweat, and loss of appetite and had no interest or desire to do activities.

"Kalau depresi itu kurang energi, terus dari fisik maupun mental pembawaannya minatnya ndak ada, tidak ingin ngapa-ngapain, terus untuk melakukan aktifitas lainnya kurang mood. Fisik merasa lemes, keringet dingin, nafsu makan nggak ada, lesu." (M. 1585-1595)

"I feel the lack of energy during the depression, from physical and mental I have no intention to do anything and I have no mood to do activities. I feel weak physical, cold sweat, loss of appetite, and fatigue." (M. 1585-1595)

In a depressed state, informant $M$ could not think clearly and easily get irritated. This condition occurs when informant $M$ experienced an event and was unable to direct himself to understand the cause of the event. Even though informant $M$ realized that every event is the result of other events.

"Depresi yang berlebih, sampai kita ndak bisa memakai logika, tergesa-gesa, emosi di jalan, mungkin seperti itu contoh kecilnya. Misalnya kita lagi di jalan, kepanasan, tiba-tiba ditabrak, kan kita emosi, titik didihku seperti itu. Kayak logika ndak bisa maapin, cari tahu dulu, ini kenapa nabrak, apa dia karena buru-buru, nah itu" (M. 341-349)

"Konsentrasi turun, tidak bisa fokus, naik motor hampir jatuh karena keseimbangan kurang. Kurang bisa berpikir positif." (M. 1585-1595)

"Severe depression makes us cannot think logically, always in hurry, get irritated while driving, for example. When driving on a hot day and someone bumps my vehicle, we'll get irritated, I will explode at that moment. It is unforgivable, not finding the reason like why 
he crashes into my vehicle, 'is he in hurry?." (M. 341-349)

"My concentration decreases, I cannot focus, I almost fell from my motorcycle because of poor balance. I cannot think positively." (M. 1585-1595)

When the informant could not think clearly, he could not understand words when interacting with others and he immediately got irritated, with or without a problem. Beck (1967) proposes that maladaptive cognitive schemas are responsible for the self-depressed mindset of depressed individuals. Cognitive schemes guide the selection and interpretation of information from the environment. It is believed that cognitive schemes of depressed individuals consist of negative thoughts about themselves, the world, and the future. Therefore, when encountering such situations, both positive and negative, the informant's perspective tends to be negative and emotional even to the extreme level.

"Sekarang aku bisa, bisa lebih tahu, semisal logikaku sudah turun, aku ndak bisa mencerna lagi kata per kata. Misal ada temen yang kontak, apa aku lagi gambar, wah ini udah males saja, wah ndak beres nih, kayak bawaannya tetep beda. Kayak cewek mens, persis itu, bawaannya kayak gitu. Bawaannya ndak enak. Ya sama. Rasain kayak gitu aku." (M. 670-692)

"Konsentrasi turun, tidak bisa fokus, naik motor hampir jatuh karena keseimbangan kurang. Kurang bisa berpikir positif." (M. 1585-1595)

"Now, I know it well, when my logic gets lost, I can't understand word by word. For example, when my friend contacts me, when I am drawing, I suddenly get moody, something is wrong. It's like women in their period, I feel the same. The feeling is so uneasy. Well, I feel the same." (M. 670-692)

"My concentration decreases, I cannot focus, I almost fell from my motorcycle because of poor balance. I cannot think positively." (M. 1585-1595)

Informant $\mathrm{M}$ once attempted suicide by riding a motorcycle. Bipolar disorder is characterized by obvious mood swings with repeated cycles (hypo) of mania and major depressive episodes which include chaos, emptiness, hopelessness, the stigma of oneself, catastrophe, guilt, and suicidal thought (Angeler, Allen, \& Persson, 2018). One of the contributors to decreased life expectancy in people with bipolar disorder is suicide. Previous research found that up to $20 \%$ of people with bipolar disorder (mostly untreated) ended their life with suicide and 20-60\% of them attempted suicide at least once in their life (Dome, Rihmer \& Gonda, 2019).

"Sempet, kacau itu, parah. Kecelakaan, ini kan dulu (menunjuk ke kakinya) sini lah, hancur gitu. Nyobain bunuh dirinya pake motor ngebut" (M. 1001-1004)

"I once did, it was chaotic. The accident was in the past (pointing his leg), it was severely injured. I attempted suicide by riding a motorcycle." (M. 1001-1004)

From the explanation above, it was revealed that during the depression, informant $\mathrm{M}$ lost interest and desire, was lack of energy, was physically weak, and had a cold sweat, had no appetite, could not think clearly (logically), easily got irritated, had negative thoughts, and attempted suicide. This depression phase is characterized by decreased energy, poor self-esteem, sleep disturbances, loss of interest, difficulty in making decisions, loss of appetite, and suicidal thoughts. The depression phase is also associated with low motivation and decisions (Greenwood, 2020). In some people with bipolar disorder, the depression phase is also accompanied by physical symptoms, which is 
migraine (Tinambunan, Amir, Budiman, \& Kusumaningrum, 2018).

In the manic phase, there is an extreme increase in mood. This phase is characterized by symptoms of increased energy, the appearance of various thoughts, quick topic shifting, increased self-esteem, reduced sleep time, poor judgment, extreme happiness, and involvement in risky activities (Greenwood, 2020). In a manic state, the informant did many activities in a day and wanted to move frequently.

"Ya ini lagi kondisi manik. Selama mata terbuka aktivitas semua. Bersih-bersihnya lama, mulai dari nyapu, ngepel, nyuci, nyangkul rumput, bakar-bakar sampah, bahkan buang sampah di sekitar rumah warga. Mau aktivitas atau gerak terus, maunya gerak terus" (M. 1602-1608)

"This is the manic condition. When my eyes open, I will do everything. I'll do cleaning, from sweeping, mopping, washing clothes, mowing grass, burning trashes, even littering on other's houses. I want to do activities and keep moving." (M. 1602-1608)

The feeling of people with bipolar disorder easily changes from depression to manic and the relapse is uncertain. Relapse occurring in people with bipolar disorder disrupts social functions, employment, married life, and even increases the risk of suicide (Santoso, Wubhawa, Ishartono, \& Venty, 2018). Dean, Gerner, and Gerner (2004) also explain that people with bipolar disorder experience a decrease in quality of life during relapse, marked by disturbances in life functions, difficulty in finding a job or struggling in the current job, and difficulties in social interactions. Pharmacotherapy intervention does not have a significant effect on relapse of people with bipolar disorder. One of the factors is noncompliance with medications prescribed by doctors (Batista, Baes, \& Juruena, 2011).

\section{Description of synesthesia experienced}

Informant M's bipolar condition is also accompanied by synesthesia. Synesthesia is a rare experience, in which one characteristic of the stimulus evokes a second experience that is unrelated to the first, for example, in lexical synesthesia, the experience of spoken words can evoke the taste experience (Banissy, Jonas, \& Kadosh, 2014). People with mirror-touch synesthesia report the sensation of touch on their own body when they see another person being touched, it indicates an increase in tactile (Brang \& Ramachandran, 2011; Ward, Schnakenberg, \& Banissy, 2018).

The synesthesia experienced by the informant is mirror-touch synesthesia which makes him has greater empathy than the average person. He can feel what other people feel deeply. Mirror-touch synesthesia is associated with a broader tendency to experience feelings from others (emotional contagion) and possibly other forms of social transmission and reflects a greater sense of social awareness (Martin, Cleghorn, \& Ward, 2017). When informant M was on the road and saw the ambulance, he thought about what if he were in that person's shoes. Furthermore, when he saw other people feeling down and sad, he also felt the same way. Personally, the informant had the same feelings and emotions as others. Informant $M$ also experienced this situation. When he was on the road and saw people racing, the informant would do so. This incident made him distracted, uneasy, and unable to control himself when he got carried away. According to Informant $\mathrm{M}$, the difficult thing to control is the time he got carried away so he felt $90 \%$ of his life is someone else's life.

"Kalau sinestesia itu yang wah, kalau orang ngebut ikut ngebut, bukan ikut-ikutan enggak, itu emang bener-bener nggak bisa ngehindarin, makanya aku jarang keluar salah satunya karena itu, Ini lho, takute kalau nggak fokus itu, takut aku, nggak konsen, karena kebawa itu, itu yang 
sempet aku takutin kalau berkendara itu, tentang sinestesia yang bikin aku khawatir, kalau yang bipolar nggak begitu" (M. 1137-1150)

"Kasusnya lebih sulit, beda, pokoknya semua motorik ini, sense nya nyambung jadi satu. Makanya 90\% aku ini hidup orang lain" (M. 192-197)

"This synesthesia is unbelievable. When I see some racing, I will do the same, it is inevitable. So I rarely go outside because of this. I am afraid when I don't focus, not concentrate because I get carried away. I am afraid of this the most when riding, this synesthesia scares me, the bipolar is not quite much.” (M. 1137-1150)

"The case is more difficult, different. All motoric nerves become connected. So, $90 \%$ of my life is someone else's life." (M. 192-197)

The informant's effort to be more focused and calm is by paying attention to the sense of taste or the lips of his speech partner when interacting.

"Biasanya aku lebih sering lihat ke indera pengecapan, supaya lebih fokus, kalau lihat ke mata takut ke bawa. Atmosfernya itu takut kena masalah, malah ikut ngedown. Kalau ada orang sedih biasanya ikut sedih" (M. 223-227)

"I usually look at the sense of taste to be focus, if I look at the eyes, I'm afraid I get carried away. I'm afraid the atmosphere will cause another problem and makes me down. If others are sad, I will get sad." (M. 223-227)

The synesthesia experienced caused concern to informant $M$ so that it was difficult to fully concentrate and easily carried away by his surroundings, which were unrelated to him. Informant $\mathrm{M}$ hoped to meet fellow synesthesia sufferers so they can share stories about their experiences. Informant's feeling is in line with the research by Parker, Paterson, Romano, and Graham (2017) that people with bipolar disorder during manic and depression episodes, they experience changes in the main senses, which are smell, taste, sight, touch, hearing, as well as other sensory phenomena such as changes in dangerous perception, intuition, empathy or connectedness, and synesthesia. His empathy is that he felt connected to everything and everyone around him so he easily got carried away. He could feel everything he saw.

"Pengin ketemu yang lain, temen yang lain, satu aja di sini. Kalau ada itu, asik juga cerita bareng. Tapi susah nemuin” (M. 1205-1208)

"Orang ngobrol itu kayak keluar angka-angka, itu yang biasa, tapi yang sulit itu kayak punyaku, genetik ini” (M. 192-197)

"I want to meet other sufferers, even one person. If I met one, it would be great to share stories. But it's difficult to find one." (M. 1205-1208)

"When people talking I see numbers, it is very common, but like one that I suffer is very rare, this genetic." (M. 192-197)

Another uniqueness of the synesthesia experienced by informant $M$ is being able to see numbers when communicating. Synesthesia is an uncommon phenomenon in which stimulation within one sensory modality arises additional similar experiences. These additional experiences can occur in the same sensory modality (e.g. seeing colors when reading achromatic letters: graphemecolor synesthesia) or in different sensory modalities (e.g. seeing colors when listening to music: sound-color synesthesia) (Chiou, Stelter, \& Rich, 2013). Visual experiences in synesthesia caused 
by auditors appear as geometric objects, consisting of colors and shapes (and sometimes textures), which appear in a specific location. Visual experiences are caused by different instrument sounds, consistent over time, and systematically varying in colors, shapes, and spatial locations in response to changes in auditory tone and sound color (Spence, 2011).

Based on the explanation above, the synesthesia of informant $M$ is a condition that causes deep empathy in informant, easily gets carried away and can see numbers when interacting with others, making it difficult to concentrate and worry about things that cannot be controlled while getting carried away.

\section{Catharsis in Depression}

When informant $\mathrm{M}$ was depressed, he chose not to interact with other people for fear of not being able to control his emotions so he chose to remain silent. The informant also slammed objects around him to vent his emotions.

"Wah nggak, nggak, nanti aku takut salah ngobrol, daripada aku bentak, sekarang mending diem, pengin banting sesuatu” (M. 693-695)

"No, no, I'm afraid of miscommunication, before I yell it's better to remain silent, I want to slam things." (M. 693-695)

Catharsis (in the clinical model) is the reduction of negative affective by taking certain actions. Catharsis occurs at several points after the negative affective is experienced (Gentile, 2013). Catharsis done by the informant is leaving the house and riding a motorbike at a high speed. It is the catharsis done by the informant.

"Terus kalau ndak, keluar lah, keluar dari rumah" (M. 702-703)

"Naik motor aja. Pokoknya ngebut yang penting jangan sampai nabrak" (M. 704-705)

"If no, I leave the house." (M. 702-703)

"I ride motorcycle. With a high speed as long as I don't crash other." (M. 704-705)

Catharsis focuses on the therapeutic (healing) value of expressing powerful emotions in a structured therapeutic. The catharsis method used by the informant during depression is classified as maladaptive because it causes a negative state and may increase depression. It is different from the catharsis through art therapy media which is more adaptive because it is considered capable of improving psychosocial function (Fletcher, Parker, \& Manicavasagar, 2013).

To improve welfare and quality of life and fulfill their developmental tasks, early adults with bipolar disorder require efforts to survive in every phase. Relapse in people with bipolar disorder is inevitable so the individual focus must be centered on dealing with the condition during relapse to survive and have resilience. An effort that can be done is to choose an emotional channeling strategy. It is feared that inappropriate emotional channeling may bring a destructive impact on individuals and their external environment. Therefore, constructive emotional channeling is required. This constructive emotional channeling by Freud is called catharsis (Wahyuningsih, 2017)

The catharsis process provides an opportunity for individuals to express disturbing emotions appropriately so as to reduce emotional stimulation and the tendency to aggressively attack others (Wahyuningsih, 2017). Baron and Byrne (2004) explain that catharsis activity is an effective instrument to reduce overt aggression. The informant in this study tended to express emotions destructively during a depression phase, such as slamming objects around him. However, informant 
M had an activity that he liked and engaged in drawing. This activity helped the informant channeled his emotions during the depression as well as became a catharsis medium.

\section{Art as a Catharsis Medium}

When in a state of bipolar condition (between manic or depression), informant $\mathrm{M}$ used catharsis, including art therapy, yoga, grounding, and mirroring.

"Art therapy itu sama seperti aku menjadi ini, art therapy itu diketahui juga dan berbarengan bersama bipolar dengan sinestesia itu berbarengan, ternyata setelah aku telusuri, karena saya kecilnya menggambar" (M. 728-733)

"Namanya kalau orang-orang tuh nyebutnya yoga tapi ini groundingnya tub kita lebih interaksi ke alam. Membawa energi, biar depresiku bisa dialihkan lewat aliran air itu," (M. 816-822) "Iya, grounding terus yoga," (M. 1168)

"Dulu aku sama psikolog dikasih metode itu juga, sama, selain grounding, mirroring, itu juga dikasih tau, nih coba kamu mirroring, biar kamu tahu dirimu sendiri" (M. 1216-1220)

"Art therapy is like, I know art therapy along with bipolar and synesthesia, after I retrieved, I used to like drawing when I was a kid.” (M. 728-733)

"People call it yoga but this grounding is more likely interaction with nature. To bring in energy so my depression can be channeled through water stream." (M. 816-822)

"Yes, grounding and after that yoga." (M. 1168)

"My psychiatric used to give me this method, besides grounding, mirroring, I was given mirroring so I know myself well." (M. 1216-1220)

Among the various catharsis medium, informant $M$ often used art therapy. Art therapy is an intervention technique that combines art and psychology (Sholihah, 2017). Art therapy is based on the idea that the creative process of making art facilitates recovery and is a form of nonverbal communication of thoughts and feelings. The primary use of art in art therapy differs from other psychotherapy approaches, as individuals in art therapy are encouraged to express themselves visually in the form of activities; building, arranging, mixing, touching, printing, pasting, drawing, photographing, documenting, making films and so on (Malchiodi, 2011). The art activity carried out by informant $\mathrm{M}$ was drawing. The drawing media was chosen because, since childhood, informant $\mathrm{M}$ has been fond of drawing. Informant $\mathrm{M}$ just learned about the term art therapy along with the bipolar and synesthesia diagnoses.

According to the informant's experiences, while using art therapy, the informant felt comfortable while drawing. Even before the informant knew about his bipolar disorder. So, the informant had done art therapy long before he knew about art therapy.

Spaniol (2001) reveals the relationship between art and mental illness and suggests that art can be used for insight and emotional growth. Scientific research on art therapy and bipolar disorder is frequently studied to examine the impact of art therapy in a group with a mixed psychiatric diagnosis (Drapeau \& Kronish, 2007). Drapeau and Kronish (2007) gathered a group of psychiatric patients to be treated with art therapy, including bipolar patients. As a result, the art therapy program showed positive results for all participants. Chandraiah, Ainlay Anand, and Avent (2012) also found evidence that the use of short-term group art therapy could reduce depression symptoms in a heterogeneous sample of psychiatric outpatients.

"Iya, nah karena itu aku pas bipolar tadi juga nggak terdeteksi, terus bareng di situ aku nggambar juga, jadi pas aku nggambar, oke aku ngerasa enak nih, kok jadi enak ini, tapi belum 
tau bipolar. Belum tau apa itu" (M. 756-760)

"So, when I was bipolar just now could not be detected, and I also drew. So, when I drew I felt a lot better. But, I had no idea what bipolar is." (M. 756-760)

The informant began to apply art therapy in his daily life while at home. When relapses, the subject exerted his emotion by immediately drawing. If the relapse was felt while outside the home, the informant could not immediately apply art therapy. When the informant was in a depressed phase, he drew for 3 to 4 hours until he felt his depression get better.

"Kadang ndak bisa aku, kemarin aku ndak bisa itu, karena posisinya memang pas di luar. Kalau pas di depan, pas lagi di rumah bisa langsung, pokoknya nyorot-nyorot apa, biasanya realis aku, gambar hantu" (M. 713-717)

"Sampai turun itu, 3 sampai 4 jam butuh, sampai aku lupa, aku kan hampir, pasang headset, gambarin" (M. 725-727)

"Sometimes I can't do that because I am outside my home. When I'm home I will immediately draw, random scribble, I usually prefer realist, ghost drawings.” (M. 713-717) "Until it gets better, I need 3 to 4 hours until I forget. I use headset and draw." (M. 725727)

Informant $\mathrm{M}$ explained that the pictures he often drew when he was depressed were realist drawings and doodles of ghosts or monsters. His depiction during the depression phase is characterized by a complex and more detailed character. Informant $\mathrm{M}$ also stated that the results of the depressed picture are always the best picture.

"Justru yang gambar rumit-rumit itu, bagus-bagus itu, pas depresi aku" (M. 719-720)

"...biasanya realis aku, gambar hantu” (M. 717)

"Iya, ada juga yang, itu sebagian yang simple-simple, itu yang monster-monster, itu memang ada yang manik ada yang depresi. Pokoknya yang depresi itu pasti gambar yang paling bagus" (M. 721-724)

"Aku kemarin sempat searching Hanna Madness, ternyata baru tahu kalau dia yang bikin gambar-gambar doodle, kalau mas $M$ kalau ngambar itu yang digambar apa pas lagi depresi?" "Ya ini, (sambil mengarah ke gambar di selembar kertas yang dibawa, yaitu doodle)" (M. 1556-1560)

"Actually the complicated pictures are the best ones, when I am depressed." (M. 719-720) “...I usually prefer realist, ghost drawings." (M. 717)

"Some of them are simple, the monster drawings are manic and depression. My point is my drawings when depression are the best ones." (M. 721-724)

"I ever searched Hanna Madness and I just knew that she does doodles, and Mr. M what kind of drawings do you do when you're depressed?" "Well, this is (taking his doodles in a piece of paper)” $M .1556-1560$ )

Informant $\mathrm{M}$ enjoyed every process in art therapy, even though he had not yet found its meaning.

"Kalau makna belum nemu, aku belum nemu maknanya apa, bukan ke maknanya, lebih ke prosesnya sekarang. Menikmati setiap prosesnya," (M. 1486-1492) 
"There is no meaning, I haven't found the meaning yet. It's not only the meaning but the process. Enjoying every process.” (M. 1486-1492)

According to informant $\mathrm{M}$, art therapy is a proper method to deal with bipolar conditions. "Art therapy sampai sekarang masih jadi metode yang tepat, tapi nggak tau kalau ODGJ, ODS lainnya," (M. 1379-1382)

"To this present, art therapy is the proper method but I don't know if it is for people with mental illness or people with schizophrenia." (M. 1379-1382)

Informant $\mathrm{M}$ had an understanding of the art therapy that he chose, which is a life lesson. The life lesson referred to by informant $\mathrm{M}$ is the process of enjoying life, accepting oneself, and being grateful.

"Oh kalau art therapy, aku anggap ini sebagai pelajaran kehidupan, aku masih belajar, aku suka menjadi pembelajar. Art therapy sampai sekarang masih jadi metode yang tepat," (M. 1376-1379)

"Iya, jadi untuk menerima terus, istilahnya untuk bersyukurlah, aku nggak mau ngelawan, menerima ini dan akan menjalani terus. Nggak pa-pa meskipun berat, emang, resiko pasti ada, tapi ya udah ndak papa, pasti ada, di balik ini semua kan pasti ada rejeki, aku percaya itu." (M. 15-22)

"Well, art therapy, I consider it as a life lesson, I like being a learner. To this present, art therapy is the proper method," (M. 1376-1379)

"To accept myself, or in other words being grateful, I won't resist, I will accept and live with it. It doesn't matter even when it's hard, well there must be a risk, but it's okay. There will be a blessing for me behind this fate, I believe that." (M. 15-22)

Informant $\mathrm{M}$ diagnosed with bipolar and synesthesia has been doing art therapy as a catharsis to survive. Stacey and Stickley (2010) studied people with mental illness and found mental health benefits from arts, such as art as a way of coping, expressing, and building relationships with others. The positive effect gained by informants is related to how to solve the problem - the informant was aware of the problem he experienced and tried to accept it and live with it. The informant was also able to build relationships with other people, living by sharing experiences about the therapeutic techniques he applied, and inspiring others. Stacey and Stickley (2010) have provided valuable findings from their research to capture qualitative data regarding arts and mental health. The art of drawing used as art therapy was stated by informant $\mathrm{M}$ to have a positive impact on his psychological condition or mental health.

\section{The Impact of Catharsis through Art}

The catharsis medium used by informant $M$ has a positive effect on psychological conditions, namely:

1) Able to direct informant to choose media according to his needs during the depression.

The various number of catharsis made informant $\mathrm{M}$ able to direct him to choose media according to his needs when he was depressed. When his depression recurred, informant $\mathrm{M}$ directed himself to be strong. He followed the direction of his urge to find calmness. If the direction was to draw, then informant $\mathrm{M}$ would draw. If informant $\mathrm{M}$ wanted to do grounding, he would do it, as well as other catharsis methods. 
"Sekarang aku ikutin, ini arahnya ke mana ya? Aku harus kuat ini, oke aku kuat, kayaknya aku harus nggambar nih, oke aku nggambar, ini harus ngobrol, oke aku ngobrol, kalau aku pingin aktivitas lihat bunga, aku lihat bunga, aku kepingin jalan aku jalan, aku nggak mau lawan itu" (M. 935-942).

"I follow where the direction is. I have to be strong, when I want to draw, I will draw, when I want to talk, I'll talk, when I want to see flowers, I will see flowers, I want to walk, I will walk, I won't resist anymore." (M. 935-942).

The media used by informant $\mathrm{M}$ were able to strengthen himself during the depression.

2) Have the awareness to face problems

Informant $\mathrm{M}$ realized that he couldn't get out of his depression. That the conditions he must face. For this reason, informant $M$ tried to make peace with himself.

"Saya tidak bisa keluar dari depresi, ini ada problem di depan, jadi ya saya harus menghadapi, saya harus bertatap muka dengan problem, yuk kita ngobrol yuk, yuk kita damai yuk, kalau kita menghindari maka lilitan permasalahan itu semakin rumit, kan akan kembali lagi kan, yang penting nggak menghindar, nanti tetap akan kembali lagi" (M. 1275-1284)

"I can't get out of this depression, if there is a problem, I must face it. Let's talk about it, let's make a peace, if I avoid it then it will get complicated. I'll be back as long as I don't avoid it, eventually, I'll be back." (M. 1275-1284)

3) Share experiences with others regarding the therapeutic techniques he applied.

The positive effect felt when applying catharsis media encouraged informant $\mathrm{M}$ to share experiences with others. Informant $M$ introduced the techniques he knew to other people, especially people with mental illness (ODGJ) and people with bipolar disorder (ODB).

"Iya, nah tapi dengan aku jadi seperti ini aku malah justru lebih sadar, lebih realistis, makanya kubilang tadi aku mengedukasi masyarakat, jadi apa yang kutahu aku coba kembalikan ke lingkungan lagi. Coba memberikan edukasi. Ini lho aku sudah melewati hal seperti ini" (M. 343)

"Well, through this I finally realize, become more realistic, as I told you I educate people, what I know I will give it back to my surroundings. Giving education. I've been through this condition." (M. 343)

4) Able to accept and be grateful for the conditions and achievements.

Informant $\mathrm{M}$ felt gratitude and was able to accept bipolar and synesthesia conditions he suffered. Informant $M$ strengthened himself not to complain and directed himself to be grateful so he would be calm. Informant $M$ wanted to prove to others that he could find achievements through his works.

"Rasa syukur pasti ada, pertama rasa syukur, aku dah bisa, jadi temenku, kita buat sesuatu nih, yuk kita dengan ini, oke aku terima nih, dengan kondisi seperti ini, tapi aku harus bisa nih, dengan kondisi seperti ini membuktikan ke orang lain bahwa aku bisa lebih, bisa berprestasi dengan ini, dengan bipolar, dengan sinestesia, aku bisa, dengan nggambar ini, aku terima oke, gantian bikin karya lewat depresi, jadi prestasi, nih, juga pembuktian ke temen-temen, ini 
kondisiku seperti ini, ada hasil. aku malah ngajak ke positif, dengan kondisi seperti ini, aku tidak mengeluh, berdamai, tha yang lain gimana? Ayo jangan ngeluh, kondisiku yang rumit, masih bisa bersyukur, gitu, jadi tenang, kalau tenang, tenang. Bisa nggambar" (M. 884-903) "I will always be grateful, I can do it. As friends, let's do something. I accept my life, my condition, but with this condition I have to prove to people that I can do more, I can get achievement, with bipolar and synesthesia, I can do it. By drawing, I'll accept reality and now I can turn works through my depression to become an achievement. I also want to prove to my friends, my condition yields something. I even ask people to do positive things. I don't want to complain about this condition, I accept it. So, how about you? Don't complain, my life is complicated but I am grateful so I find peace. If I find peace, I can draw." (M. 884-903)

5) Understand the importance of a positive mindset to encourage oneself.

The catharsis made informant $\mathrm{M}$ calmer and able to think positively during relapses. For $\mathrm{M}$ informants, mindset is important to create inner peace, especially when negative stigma attacks from the surroundings.

"Terus positifnya jadi tau, nih Mada di titik ini, M bisa. Ternyata dengan ini bisa menghasilkan, jadi lebih banyak positifnya. Saya nggak mau melewatkan begitu saja, kalau melewatkannya saya nggak bisa berdamai, diambil terus positifnya, nanamnya ke pola pikir. Saya lawan dengan pola pikir, ini depresi gapapa, dikatain ODB gapapa, stress gapapa, biarin" (M. 1414-1423) "So, the positive side is like, Mr. M is at this point and can do it. Actually, by creating, you gain more positive things. I won't let it pass, if I let it go I can't make peace with myself. I will always see the positive side, I instill it into my mindset. I resist with my mindset, this depression is nothing, it's okay if I am yelled bipolar, or stress." (M. 1414-1423)

6) Feel the serenity

Catharsis has a positive impact on informant M's calmness.

"Tadi, lebih ke awal benang merahnya tadi, tenang, itu hasilnya itu" (M. 1540-1546)

"So it comes back to the underlying causes, I find serenity, that's the result." (M. 15401546)

7) Can reflect oneself through the drawing

Informants $\mathrm{M}$ enjoyed the process of self-reflection or mirroring. This was done by absorbing thoughts about the meaning of the shapes and colors of the images.

"Terus kalau ada untuk bercermin, apa sih ini, maksudnya 'apa sih ini' itu ehhmm, M kadang belajar dari gambar ini, dari warna dari ini, sebenernya $M$ cari maksudnya apa sih?, Tuhan kok ngasih pemikiran ini?" (M. 1540-1546)

"And when I reflect, like 'what is this?', well, uhm. M sometimes learns from drawing, from colors, actually $\mathrm{M}$ tries to find 'what does it mean?' Why God never gives this though?” ( $M$. 1540-1546)

8) Works from art therapy have the potential to become a source of livelihood

During the art therapy process, informant $M$ realized that the results of art therapy 
in the form of works of art have the potential to become a source of livelihood.

"Tadi, lebih ke awal benang merahnya tadi, tenang, itu hasilnya itu. Jadi potensi yang lebih lagi M bisa hidup dari situ." (M. 1549-1552)

"So it comes back to the underlying causes, I find serenity, that's the result. Moreover, M can live from works of art." (M. 1549-1552)

9) Inspire others

According to informant $\mathrm{M}$, an important result of art therapy is to inspire others.

"Iya, yang penting ini hasilnya yang lebih lagi M bisa menginspirasi yang lain, itu sebenarnya." (M. 1553-1555)

"The most important is $\mathrm{M}$ can inspire others, that's the point." (M. 1553-1555)

Furthermore, the positive impact of art therapy is an achievement, relaxation/calmness, and freedom (Stacey \& Stickley, 2010). The achievements of the informant $M$ as a positive impact of art therapy are works of art that have the potential to become a source of living. The fun aspect of creating art is to help an individual to overcome emotions and release negative experiences during the process so that informant $\mathrm{M}$ felt calm as an effect of art therapy catharsis (Czamanski-Cohen \& Weihs, 2016). Also, informant $\mathrm{M}$ gained freedom so that he was able to choose the media according to his needs during the depression.

In addition to the benefits of art on mental health, Stacey and Stickley (2010) also found the meaning of art for people with mental illness. According to informant $\mathrm{M}$, he was able to reflect on himself through the work he drew. It was carried out by absorbing the thoughts arising about the meaning of the shapes and the colors of the images. Besides, the informant could understand the importance of a positive mindset to strengthen himself, especially in dealing with a negative stigma.

Another positive impact is that informant $\mathrm{M}$ could accept and be grateful for the conditions he experienced. Emmons \& McCullough (2004) and Elosúa (2015) found that gratitude is associated with positive emotions, psychological and physical well-being, social relationships, and spirituality. Research data by R. A. Emmons \& Kneezel (2005) and Elosúa (2015) show that measurements of spirituality are significantly related to the nature of gratitude and feelings of gratitude recorded in the diaries of people with neuromuscular conditions. Spirituality exists in everything and is also intimate in therapy sessions, including in art, and spirituality is an indispensable element of psychotherapy (Kırca, 2019). The study by Kırca (2019) was designed as an art therapy program that made use of Rogerian's steps and principles, finding that art therapy was effective at promoting spiritual development. The informant also stated that with gratitude he felt calm and became a strength to gain achievement with bipolar and synesthesia he experienced.

\section{CONCLUSION}

The results of this study reveal that art can be used as a catharsis medium in informant diagnosed with bipolar and synesthesia. Catharsis through art therapy in the form of drawing can help informants to cope with the bipolar condition during manic or depression episodes. The images produced by the informant reflect affective conditions and his changes - images in the depression phase are more expressive and detailed than the manic phase. Drawing activities make informants feel comfortable. Art therapy is defined as a life lesson about enjoying life, accepting 
oneself, and being grateful. This research implies that art therapy has a positive impact on the informant. On the other hand, the success of art therapy is influenced by the informant's interest in art therapy. The informant's awareness of the condition he experiences has an important role in recognizing the time to start drawing therapy activities.

The findings in this study can be used as input in the clinical psychology field to help patients become aware of their condition and encourage them to find suitable catharsis activities or media when dealing with sudden changes in affective conditions. Images produced by patients in art therapy can be used by clinical psychologists as additional data in the assessment to obtain a picture of the affective they experience.

\section{REFERENCES}

Agustina, A. (2018, April 2). BCI sebut ada 2 persen masyarakat Indonesia mengidap gangguan bipolar. Merdeka.com. Retrieved from https://m.merdeka.com/bandung/halo-bandung/ bci-sebut-ada-2-persen-masyarakat-indonesia-mengidap-gangguan-bipolar-1804026.html Accesed ...

Aktu, Y., \& İlhan, T. (2017). Individuals' life structures in the early adulthood period based on Levinson's Theory. Educational Sciences: Theory \& Practice, 7(14), 1383-1403. https://doi. org/10.12738/estp.2017.4.0001

Angeler, D. G., Allen, C. R., \& Persson, M.-L. (2018). Resilience concepts in psychiatry demonstrated with bipolar disorder. International Journal of Bipolar Disorders, 6(1), 1-8. https://doi.org/10.1186/s40345-017-0112-6

Anggitasari, A., \& Zaini, I. (2020). Ciri khas gambar pada anggota komunitas doodle art surabaya. Jurnal Seni Rupa, 8(2), 54-63. Retrieved from https://jurnalmahasiswa.unesa.ac.id/index. $\mathrm{php} / \mathrm{va} /$ article/download/35579/31637

Banissy, M. J., Jonas, C., \& Kadosh, C. R. (2014). Synesthesia: an introduction. Frontiers in Psychology, 5, 1-3. https://doi.org/10.3389/fpsyg.2014.01414

Baron, R. A., \& Byrne, D. (2004). Psikologi sosial (Djuwita, R., Trans.). Jakarta : Erlangga.

Batista, T. A., Von Werne Baes, C., \& Juruena, M. F. (2011). Efficacy of psychoeducation in bipolar patients: Systematic review of randomized trials. Psychology \& Neuroscience, 4(3), 409-416. https://doi.org/10.3922/j.psns.2011.3.014

Beck, A. T. (1967). Depression: Clinical, experimental, and theoretical aspects. Philadelphia: University of Pennsylvania Press.

Brang, D., \& Ramachandran, V. S. (2011). Survival of the synesthesia gene: Why do people hear colors and taste words? PLoS Biology, 9(11), 1-6. https://doi.org/10.1371/journal. pbio. 1001205

Chandraiah, S., Ainlay Anand, S., \& Avent, L. C. (2012). Efficacy of group art therapy on depressive symptoms in adult heterogeneous psychiatric outpatients. Art Therapy, 29(2), 80-86. https://doi.org/10.1080/07421656.2012.683739 
Chiou, R., Stelter, M., \& Rich, A. N. (2013). Beyond colour perception: Auditory-visual synaesthesia induces experiences of geometric objects in specific locations. Cortex, 49(6), 1750-1763. https://doi.org/10.1016/j.cortex.2012.04.006

Czamanski-Cohen, J., \& Weihs, K. L. (2016). The bodymind model: A platform for studying the mechanisms of change induced by art therapy. The Arts in Psychotherapy, 51, 63-71. https:// doi.org/10.1016/j.aip.2016.08.006

Dean, B. B., Gerner, D., \& Gerner, R. H. (2004). A systematic review evaluating healthrelated quality of life, work impairment, and healthcare costs and utilization in bipolar disorder. Current Medical Research and Opinion, 20(2), 139-154. https://doi. org/10.1185/030079903125002801

Dome, Rihmer, \& Gonda. (2019). Suicide risk in bipolar Disorder: A brief review. Medicina, 55(8), 403. https://doi.org/10.3390/medicina55080403

Drapeau, M.-C., \& Kronish, N. (2007). Creative art therapy groups: A treatment modality for psychiatric outpatients. Art Therapy, 24(2), 76-81. https://doi.org/10.1080/07421656.20 07.10129585

Elosúa, M. R. (2015). The influence of gratitude in physical, psychological, and spiritual wellbeing. Journal of Spirituality in Mental Health, 17(2), 110-118. https://doi.org/10.1080/1 9349637.2015.957610

Emmons, R. A., \& Kneezel, T. T. (2005). Giving thanks: Spiritual and religious correlates of gratitude. Journal of Psychology and Christianity, 24(2), 140-148. Retrieved from https:// psycnet.apa.org/record/2005-09753-006

Emmons, Robert A., \& McCullough, M. E. (2004). The psychology of gratitude. USA: Oxford University Press.

Fletcher, K., Parker, G. B., \& Manicavasagar, V. (2013). Coping profiles in bipolar disorder. Comprehensive Psychiatry, 54(8), 1177-1184. https://doi.org/10.1016/j. comppsych.2013.05.011

Florez, L. F. R. (2015). Factors affecting academic resilience in middle school students: A case study. GiST Education and Learning Research Journal, 11(11), 63-78. https://doi. org/10.26817/16925777.286

Gentile, D. (2013). Catharsis and media violence: A conceptual analysis. Societies, 3(4), 491-510. https://doi.org/10.3390/soc3040491

Greenwood, T. A. (2020). Creativity and bipolar disorder: A shared genetic vulnerability. Annual Review of Clinical Psychology, 16(1), 239-264. https://doi.org/10.1146/annurevclinpsy-050718-095449

Herdiyanto, Y. K., Tobing, D. H., \& Vembriat, N. (2017). Stigma terhadap orang dengan gangguan jiwa di Bali. Inquiry: Jurnal Ilmiah Psikologi, 8(2), 121-132. Retrieved from http://journal. paramadina.ac.id/index.php/inquiry/article/view/148

Hidayah, R. (2014). The effect of art therapy on children's self-concept. Makara Human Behavior 
Studies in Asia, 18(2), 89-96. https://doi.org/10.7454/mssh.v18i2.3464

Joseph, M. C., Satiadarma, M. P., \& Koesma, R. E. (2018). Penerapan terapi seni dalam mengurangi kecemasan pada perempuan korban kekerasan dalam rumah tangga di Jakarta. Jurnal Muara Ilmu Sosial, Humaniora, dan Seni, 2(1), 77-87. https://doi.org/10.24912/jmishumsen. v2i1.1620

Kemkes.go.id. (2016). Peran keluarga dukung kesehatan jiwa masyarakat. Kementrian Kesehatan RepublikIndonesia. Retrieved from https:/www.kemkes.go.id/article/print/16100700005/ peran-keluarga-dukung-kesehatan-jiwa-masyarakat.html

Keye, M. D., \& Pidgeon, A. M. (2013). An investigation of the relationship between resilience, mindfulness, and academic self-efficacy. Open Journal of Social Sciences, 1(6), 1-4. http:// dx.doi.org/10.4236/jss.2013.16001

Kirca, B. (2019). Spiritual dimension in art therapy. Spiritual Psychology and Counseling, 4, 257274. Retrieved from https://spiritualpc.net/wp-content/uploads/2020/02/04_kirca_4-3. pdf

Lestari, W., \& Wardhani, Y. F. (2014). Stigma dan penanganan penderita gangguan jiwa berat yang dipasung (Stigma and management on people with severe mental disorders with "Pasung" (physical restraint)). Buletin Penelitian Sistem Kesehatan, 17(2), 157-166. Retrieved from http://oaji.net/articles/2015/820-1432779627.pdf

Mahpur, M. (2017). Memantapkan analisis data melalui tahapan koding. Repository Universitas Islam Negeri Malang, 1-17. Retrieved from http://repository.uin-malang.ac.id/800/2/ koding.pdf

Malchiodi, C. A. (2011). Handbook of art therapy, second edition. New York: Guilford Press.

Martin, D., Cleghorn, E., \& Ward, J. (2017). The lived experience of mirror-touch synaesthesia: A qualitative investigation of empathy and social life. Journal of Consciousness Studies, 24(1-2), 214-227. Retrieved from https:/www.ingentaconnect.com/contentone/imp/ jcs/2017/00000024/f0020001/art00009

Maslim, R. (2019). Buku saku: Diagnosis gangguan jiwa: Rujukan ringkas dari ppdgj-III. Jakarta: Bagian Ilmu Kedokteran Jiwa FK-Unika

Pardede, C. M. (2012). Karakteristik penderita percobaan bunuh diri dengan racun di RSUD dr. Pringadi Kota Medan tahun 2016-2001. Kesehatan Reproduksi dan Epidemiologi, 1(1), 4-5. Retrieved from https://jurnal.usu.ac.id/index.php/gkre/article/view/379/273

Pardian, D. (2019). Penerapan terapi suportif dengan teknik guidance untuk meningkatkan penghayatan makna hidup padapenderita gangguan bipolar di pondok pesantren al-hamid Cibubur. Jurnal Psikologi: Media Ilmiah Psikologi, 17(1), 14-19. Retrieved from https:// jpsikologi.esaunggul.ac.id/index.php/JPSI/article/view/10

Parker, G., Paterson, A., Romano, M., \& Graham, R. (2017). Altered sensory phenomena experienced in bipolar disorder. American Journal of Psychiatry, 174(12), 1146-1150. https://doi. org/10.1176/appi.ajp.2017.16121379 
Permatasari, A. E., Marat, S., \& Suparman, M. Y. (2017). Penerapan art therapy untuk menurunkan depresi pada lansia di Panti Werdha X. Jurnal Muara Ilmu Sosial, Humaniora, dan Seni, 1(1), 116-126. https://doi.org/10.24912/jmishumsen.v1i1.341

Purba, R. A., \& Kahija, Y. F. L. (2018). Pengalaman terdiagnosis bipolar: Sebuah interpretative phenomenological analysis. Empati, 6(3), 323-329. Retrieved from https://ejournal3.undip.ac.id/index.php/empati/article/view/19762

Santoso, M. B., Wubhawa, B., Ishartono, I., \& Venty, F. (2018). Pekerjaan sosial: Bekerja bersama orang dengan gangguan bipolar. Prosiding Penelitian dan Pengabdian kepada Masyarakat, 5(1), 14-22. https://doi.org/10.24198/jppm.v5i1.16019

Saputra, A., Kartasasmita, S., \& Subroto, U. (2018). Penerapan art therapy untuk mengurangi gejala depresi pada nara pidana. Jurnal Muara Ilmu Sosial, Humaniora, dan Seni, 2(1), 181 188. Retrieved from https://doi.org/10.24912/jmishumsen.v2i1.1599

Sholihah, I. N. (2017). Kajian teoritis penggunaan art therapy dalam pelaksanaan layanan bimbingan dan konseling di SMK. In International Conference: 1st ASEAN School Counselor Conference on Inovation and Creativity in Counseling (pp. 173-182). Yogyakarta: Ikatan Bimbingan dan Konseling Sekolah. Retrieved from https://www.gci.or.id/proceedings/ view_article/176/3/ascc-2017

Spaniol, S. (2001). Art and mental illness: where is the link? The Arts in Psychotherapy, 28(4), 221-231. https://doi.org/10.1016/S0197-4556(01)00108-3

Spence, C. (2011). Crossmodal correspondences: A tutorial review. Attention, Perception, \& Psychophysics, 73(4), 971-995. https://doi.org/10.3758/s13414-010-0073-7

Stacey, G., \& Stickley, T. (2010). The meaning of art to people who use mental health services. Perspectives in Public Health, 130(2), 70-77. https://doi.org/10.1177/1466424008094811

Sugiyono. (2011). Metode penelitian kuantitatif kualitatif dan R\&D. Bandung: Alfabeta.

Tinambunan, I. R., Amir, N., Budiman, R., \& Kusumaningrum, P. (2018). Komorbiditas fisik pada gangguan bipolar di RS. Dr. H. Marzoeki Mahdi Bogor. Journal of the Indonesian Medical Association Majalah Kedokteran Indonesia, 68(8), 373-377.

Triswidiastuty, S., Rusdi, A., \& Rumiani, '. (2019). Terapi dzikir untuk menurunkan simptom bipolar. Journal of Psychological Science and Profession, 3(1), 43-48. https://doi.org/10.24198/ jpsp.v3i1.21369

Wahyuningsih, S. (2017). Teori katarsis dan perubahan sosial. Jurnal Komunikasi, 11(1), 39-52. Retrieved from https://doi.org/10.21107/ilkom.v11i1.2834

Walker, P. L. M., Memmott, E. L. M. M. K., \& Nelson, L. J. (2017). Positive relationships as an indicator of flourishing during emerging adulthood. In L. M. P. Walker \& L. J. Nelson (Eds.), Emerging adulthood series. Flourishing in emerging adulthood: Positive development during the third decade of life (pp. 212-236). UK: Oxford University Press

Ward, J., Schnakenberg, P., \& Banissy, M. J. (2018). The relationship between mirror-touch synaesthesia and empathy: New evidence and a new screening tool. Cognitive Neuropsychology, 
35:5-6, 314-332. https://doi.org/10.1080/02643294.2018.1457017

Yosianto, H. F. (2013). Studi kualitatif cognitif behaviour therapy pada bipolar disorder. Character: Jurnal Penelitian Psikologi., 1(2), 1-14. Retrieved from https://jurnalmahasiswa.unesa.ac.id/ index.php/character/article/view/1861 